УДК 81 ’373 : [811.161.2 + 811.112.2]; (477+430)

\title{
ФРАЗЕОЛОГІЗМИ 3 ОНОМАСТИЧНИМ КОМПОНЕНТОМ ЯК РЕПРЕЗЕНТАНТИ НАЦІОНАЛЬНОЇ КУЛЬТУРИ (НІМЕЦЬКО-УКРАЇНСЬКІ ПАРАЛЕЛІ)
}

\author{
Віта Гаманюк, Тетяна Мішеніна \\ Криворізький державний педагогічний університет \\ Kryvyi Rih State Pedagogical University \\ пр. Гагаріна, 54, Кривий Ріг, 50086, Украӥна \\ vitana65@gmail.com,t.mishenina@gmail.com
}

Гаманюк В., Мішеніна Т. Фразеологізми з ономастичним компонентом як репрезентанти культури (німецько-українські паралелі)

У статті досліджено фразеологічні одиниці з ономастичним компонентом в українській і німецькій лінгвокультурі. Акцентовано увагу на переосмисленні біблійних виразів в українському й німецькому фразеологічному полі, установлено закономірності використання антропоніма у складі фразеологізму, розглянуто індивідуалізовані власні імена, використані задля позначення певного явища або характеристики окремих рис людини / загальної характеристики вдачі; оцінки поведінки людини відповідно до етичного кодексу; відтворення світоглядної позиції нації. Виокремлено тематичні групи, які характеризують або подають як моральний імператив закони співжиття, відтворюють народну педагогіку.

Ключові слова: фразеологізм, ономастикон, антропонім, лінгвокультура, фонова лексика, міжмовні фразеологічні кореляти.

Гаманюк В., Мішеніна Т. Фразеологизмы з ономастическим компонентом как репрезентанты культуры (немецко-украинские параллели)

У статье исследуются фразеологические единицы с ономастическим компонентом в украинской и немецкой лингвокультуре. Акцентируется внимание на переосмыслении высказываний из Библии в украинском и немецком фразеологическом поле, определяются закономерности использования антропонима в составе фразеологизма, рассматриваются индивидуализованые имена собственные, которые используются для обозначения определенных явлений или характеристики отдельных черт характера человека; оценки поведения человека в соответствии с этическими нормами; отражения мировоззренческой позиции нации. Выделяются тематические группы, которые характеризуют или подают как моральный императив законы жизни, отражают положения народной педагогики.

Ключевые слова: фразеологизм, ономастикон, антропоним, лингвокультура, фоновая лексика, межязыковые фразеологические корреляты.

-29- () В. Гаманюк, Т. Мішеніна, 2019. 
Hamanyuk V., Mishenina T. Phraseological units with onomastic component as a transfer of culture (German-Ukrainian parallels)

The article investigates phraseological units with onomastic component in Ukrainian and German linguoculture and correlations at language unit level / a transfer of culture. Types of connotative meaning that realize these units are characterized in the article. The ways of introducing them to the structure of phraseological units (rethought biblical names; derivatives of canonized baptismal names; names related to the cultural and historical path of Ukrainian and German nations) are clarified on the example of proper names. Emphasis is made on rethinking of biblical expressions in Ukrainian and German phraseological fields, corresponding unique vocabulary. The regularities of anthroponym using in phraseological units, that has an additional positive or negative colouring (rhythmforming function, functionality, typing) have been established. The individualized proper names, that are used to indicate a certain phenomenon or characteristics of individual human traits / general characteristics of a temper; assessment of human behavior according to the code of ethics; reproduction of the nation's worldview (cognitive, emotional levels of the world's knowledge) that act as a typing tool are considered. The usage statistics of certain male / female names, that are used as a structural-semantic component of phraseological units in Ukrainian and German, are given. The advantage of using male names in the studied language systems is stated. Thematic groups of phraseological units with an onomastic component, which characterize or present the laws of coexistence (family, community, society) as moral imperative, reproduce folk pedagogy (education of courtesy, diligence, etc.) are separated. Further research prospects of functioning features of phraseological units with onomastic component, which consist in the development of the translation methodology of direct / figured components are outlined.

Key words: phraseological units, onomasticon, anthroponym, linguoculture, background vocabulary, interlingual phraseological correlates.

\section{Постановка проблеми та її зв'язок із важливими} науковими завданнями. На сучасному етапі масової міжкультурної взаємодії проблема порозуміння на вербальному рівні набуває актуальності. Питання адекватного сприйняття почутого і його трактування є надважливим, а забезпечують його не тільки знання базової лексики, спроможність правильного іiі використання, а й фонові знання та розуміння безеквівалентної лексики. А. Манакін правомірно наголошує на тому, що “міжкультурна комунікація завжди передбачає пізнання інших мов і культур і супроводжується відкриттям нових реалій, які відсутні в рідній культурі. Чужою мовою важко пояснити національно-специфічні явища, які не мають прямих відповідників. Такі слова становлять безеквівалентну лексику і 
фразеологію та є специфічною фоновою інформацією” [Manakin / Манакін 2012 : 188].

Фонова інформація $є$ важливою у трактуванні семантики фразеологізмів, 3 іншого боку, фразеологізми самі по собі $\epsilon$ джерелом фонової інформації. Фразеологічні одиниці (ФО) будь-якої мови нерозривно пов'язані 3 історією, традиціями, літературою, побутом народу. Водночас вони відображають реалії, акумулюють у внутрішній формі найрізноманітніші вияви національної культури, зберігають найсуттєвіші віхи історичного розвитку. На думку М. Кочергана, “фразеологічний склад $є$ специфічною для кожної мови національно маркованою частиною лексикону. Постійно поповнюючись новими одиницями, фразеологічний склад відображає культурноісторичний досвід народу, а також особливості історичних законів розвитку мови" [Kocherhan / Кочерган 2006 : 339]. Говорячи про ФО, слід ураховувати те, що фразеологічний склад мови, як і словниковий, перебуває в постійному русі, окремі компоненти у складі ФО можуть замінюватися більш актуальними, такими, які відтворюють перебіг часу, епохальні значеннєві дескриптори. Проте $є$ й ті, що залишаються незмінними, зберігаючи своє значення.

Контрастивне вивчення мовних систем під час процедури перекладу фразеологічних одиниць дає змогу визначити особливості зіставлюваних української й німецької мов.

Вирішальним для контрастивного вивчення семантики фразеологічних одиниць 3 ономастичними компонентом зіставлюваних мов $€$ виокремлення семасіологічного й ономасіологічного аспектів. Аналіз спільного і відмінного у фразеологізмах 3 ономастичним компонентом допомагає простежити психолінгвістичні механізми мовно-кодової інформації, розширює наші уявлення про національнокультурну специфіку мовних картин світу, розкриває особливості виникнення й уживання досліджуваних власних назв як складників ФО в німецькій та українській мовах.

Аналіз останніх досліджень та публікацій. Національнокультурна специфіка ФО відтворює різні аспекти національної культури: історію народу, його вірування, ритуали, звички, 
традиції, правила повсякденного життя, цінності, мораль, особливості державного устрою тощо.

На думку М. Ковшової, національно-культурна специфіка

ФО може виявлятися на трьох рівнях: 1)у цілісному фразеологічному значенні; 2) у значенні окремих лексичних компонентів; 3) у прямому значенні вільного словосполучення, яке було переосмислено [цит. за: Lukanska / Луканська 2011 : 78]. Саме на рівні цілісного фразеологічного значення безеквівалентна лексика відіграє ключову роль, а від володіння нею залежить розуміння фразеологізму загалом. Часто така безеквівалентна лексика - це концепти національної культури, які відсутні в інших культурах (реалії, топоніми, свята, одяг тощо). Уналежнена до структури ФО, вона здебільшого унеможливлює розуміння значення фразеологізму, перетворюючи його на безеквівалентний фразеологізм.

За М. Кочерганом, “специфіка лексичного складу може виявлятися у вживанні безеквівалентних слів та слів національнокультурним семантичним компонентом" (найменування предметів побуту, музичних інструментів, одягу, національні власні назви на позначення людей і тварин); “певних слів у співвідносних компаративних фразеологізмах" (назви тварин, рослин, будівель, установ, представників окремих соціальних груп) [Kocherhan / Кочерган 2006 : 342-342].

Фонові знання $\epsilon$ передумовою розуміння змісту фразеологізмів, уналежнених до певної групи: а) $Ф О$ з соматизмами; б) ФО із зоонімами й фітонімами; в) ФО 3 кольороназвами. Найбільш залежними від фонових знань $\epsilon$ фразеологізми з власними назвами - ономастичні фразеологізми, оскільки “ім'я (назва) - це один із продуктів людської культури, оскільки виникає воно в колективі, тому й відображає риси, що йому властиві. Епоха та рівень знань людини накладає відбиток на ім'я, тому воно, своєю чергою, може повідати згодом про національні та культурні особливості тієї чи тієї епохи" [Lukanska, Oleksiienko / Луканська, Олексієнко 2011 : 76].

Ономастика має розділи, які виокремлюють традиційно відповідно до категорій власних імен: топоніміка вивчає власні імена географічних об'єктів, антропоніміка - власні імена 
людей, космоніміка -найменування зон космічного простору сузір'їв, галактик як наукових, так і народних, астроніміка назви космічних об'єктів або окремих небесних світил, зооніміка - власні імена тварин, їх клички, хрематоніміка власні імена предметів матеріальної культури, теоніміка - власні імена богів і божеств будь-якого пантеону, карабоніміка - власні імена кораблів, суден і катерів" [Poznikhirenko / Позніхіренко 2018 :27]. Власна назва будь-якої тематичної групи може виступати як компонент фразеологізму, що має певне семантичне навантаження, нерозуміння сутності якого суттєво впливає на розуміння або трактування ФО загалом.

Н. Ящик, досліджуючи лексико-семантичні особливості антропонімів-символів у німецькій мові, виокремлює кілька груп фразеологізмів 3 міфологічними, біблійними, літературними антропонімами, антропонімами на позначення історичних символів і визначних особистостей, серед яких літературні діячі, науковці, музиканти, композитори, художники, політики, філософи тощо [Yashchyk / Ящик 2017: 156-169]. Попри те, що дослідження проводилося на матеріалі слов'янських мов (української й польської), ці групи антропонімів можна виявити й у германських мовах.

Г. Луканська виокремлює такі групи ономастичних компонентів, що входять до складу ФО: 1) антропоніми, що дають широкий спектр категорій імен, що пов'язано з історією, культурою, особливостями психології, із традиціями і т. ін.; 2) фіктоніми - імена героїв творів; 3) теоніми - імена богів; 4) агіоніми - імена святих; 5) міфоніми, до складу яких входять назви тварин, рослин, народів, географічні та космічні об'єкти, імена ірреальних людей; 6) опоніми, назви географічних об'єктів; 7) геортоніми, назви свят [Lukanska, Oleksiienko / Луканська, Олексієнко 2011 : 75-76].

Очевидно, що фразеологія як віддзеркалення культури певного етносу, є частиною лексичного складу мови й відіграє важливу роль у сфері міжкультурної комунікації. Розуміння фразеологіму з ономастичним компонентом часто залежить від того, наскільки зрозумілим або відомим є ім'я чи географічна назва й увесь пов'язаний 3 ними контекст. У кожній 
лінгвокультурі наявна надзвичайно велика кількість власних назв: назви міст і містечок, окремих районів, місцин, річок і гір, вулиць, а також імен, прізвищ і прізвиськ, проте не кожна власна назва може увійти до складу фразеологізму. Навіть носій мови не завжди орієнтується у власних назвах і тому достеменно не знає, про що йдеться, адже “оніми у складі фразеологізмів здебільшого втрачають зв'язок 3 реальними денотатами i набувають узагальненого значення" [Lalaian / Лалаян 2008 : 137]. Проте оніми, які є загальновідомими і які перетворилися з власної назви на загальну, можуть входити до складу ФО, надаючи їй конкретного змісту 3 певним образним забарвленням. Як зауважує Ю. Позніхіренко, “ономастикон $є$ потужним фрагментом як національно-мовної картини світу етносів, так i частиною їх соціокультурного простору, єдиного для всього мовного колективу й водночас індивідуального для окремого його представника" [Poznikhirenko / Позніхіренко 2018 :2]. Знання власних назв i, особливо, розуміння функціонального навантаження тих онімів, які виступають компонентами $Ф О, \epsilon$ надзвичайно важливим в аспекті міжкультурного спілкування. Адже, за твердженням В. Манакіна, “фонові знання відіграють ключову роль у розумінні переносних значень власних назв" [Manakin / Манакін 2012 : 192], а їх правильна інтерпретація сприяє успішній комунікації.

Н. Лалаян пропонує генетичну класифікацію ФО 3 ономастичним компонентом у німецькій мові, що передбачає: 1) власне німецькі або корінні ФО; 2) ФО, запозичені з інших мов [Lalaian / Лалаян 2008 : 137], де до першої групи уналежнені фольклорні (народно-розмовні) фразеологізми з ономастичним компонентом, ФО книжного походження, до складу яких входять імена літературних персонажів; до другої - ФО античного, біблійного походження та запозичені 3 інших європейських мов (історичні події, постаті, герої фольклору, творів світової літератури) [Lalaian / Лалаян 2008 : 137-141].

Мета запропонованої статті - дослідження фразеологізмів, репрезентантів німецької й української лінгвокультур, структурно-семантичним компонентом яких $€$ власні імена, на рівні мовної картини світу. 
Виклад основного матеріалу. Власна назва як структурносемантичний компонент фразеологізму $є$ вторинною, оскільки зміна функції 3 номінативної на узагальнену визначає іншу реалізацію - доповнювати й уточнювати, інтерпретувати первинну номінацію.

Узагальненими компонентами ФО виступають як імена, поширені у відповідній лінгвокультурі, так і прізвища або прізвиська. Як зазначає О. Мороз, “особові імена у складі фразеологізмів не співвідносяться 3 конкретною особою, виступають денотатами багатьох осіб і набувають соціальнооцінних коннотацій” [Moroz / Мороз 2016 : 79]. Окрім того, такі оніми набувають передусім негативного забарвлення. Асоціації 3 одиничним, відомим у той чи той період часу носієм імен (реальним або вигаданим), стають основою формування додаткових конотацій: власні назви втрачають зв'язок зі своїм денотатом i набувають нових значень, тісно пов'язаних iз сутнісними характеристиками носіїв імен, що зумовлює виникнення узагальнень, перетворення імені, власної назви на загальну. Оніми мають здатність ставати ключовим компонентом ФО і сприймаються мовцями як загальне поняття. Пор.: антропоніми (er ist kein Bismarck - він не Бісмарк, тобто великим політиком його не назвеш; das kannst du halten wie der Pfarrer Assmann - роби як священик Ассманн, тобто як хочеш, за власним вибором), фіктоніми (eine Gretchenfrage stellen ставити запитання Гретхен, тобто ставити принципове запитання; Eulenspiegel machen - прикидатися Эйленшпигелем, тобто пустувати), теоніми (in Morpheusarmen ruhen - почивати в обіймах Морфея, спати, перебувати в несвідомому стані; Venus sein - бути Венерою, тобто бути дуже гарною жінкою), агіоніми (Sankt-Martin feiern - святкувати Святого Мартіна, тобто пити, веселитися; beim Schwein des heiligen Antonius schwören - клястися свинею Святого Антонія, тобто давати порожні обіцянки), міфоніми (Pegasus besteigen - осідлати Пегаса, тобто почати писати вірші; ein echter Zerberus теперішній Цербер, тобто пильний сторож). Такі фразеологізми містять у своїй структурі слова-реалії, знання яких є необхідним задля розуміння ФО загалом.

-35- С В. Гаманюк, Т. Мішеніна, 2019. 
3-поміж ФО з ономастичним компонентом у німецькій мові вирізняються фразеологізми біблійного походження. Упродовж багатьох віків християнство й розвинена на його основі християнська культура були найважливішим джерелом формування національних культур європейського континенту, які згодом поширилися на колонії європейських держав, і тому власні назви біблійного походження, використовуються у більшості європейських мов, носіями яких $є$ представники християнського віросповідання. Окрім того, фразеологізми, що містять біблійні імена, зазвичай мають однакову структуру i зберігають вихідний зміст у всіх мовах.

До таких ФО належать насамперед вислови з біблійними антропонімами, найпопулярнішими 3 яких є імена на зразок Abraham, Joseph, Adam, Eva, Noah, Methusalem, Kain, Abel, Lazarus, Salomon, Pontius. Наприклад: wie in Abrahams Schoß sitzen (sein) - жити як у раю, як у Бога за пазухою; so sicher wie in Abrahams Schoß - почувати себе в цілковитій безпеці; einen neuen Adam anziehen - стати зовсім іншою людиною; den alten Adam ausziehen - позбутися застарілих звичок, поглядів; von Adam und Eva abstammen - бути допотопним; bei Adam und Eva anfangen . починати здалеку, від Адама і Сви; seit Adams Zeiten 3 часів Адама, з сивої давнини; im Adamskostüm - у костюмі Адама; aussehen wie Leiden Christi - виглядати як страждання Христа; falsch wie Judas sein - бути фальшивим, як Йуда; Kainsmal (auf der Stirn) tragen - мати печатку Каїна; stark wie Samson sein - сильний як Самсон; Salomos Pantoffeln geerbt haben - успадкувати домашні туфлі Соломона, тобто бути мудрим; sich ernährn wie der heilige Antonius - сидіти на їжі Святого Антонія, тобто голодувати; Moses Grab suchen - шукати могилу Моїсея, тобто займатися марнию справою; einen von Pontius zu Pilatus schicken - посилати когось від Понтія до Пілата, або von Pontius zu/nach Pilatus laufen - бігати від Понтія до Пілата, тобто змушувати оббивати пороги або бігати по різних інстанціям без результату). У більшості ФО ім'я зберігає закріплені за ним асоціації. Так, Адам і $C в а$ асоціюються 3 початком, давніми часами, Соломон - мудрістю, Каӥн та Юда-зрадою. 
Нерідко натрапляємо й на біблійні ФО 3 компонентомтопоніми (über den Jordan gehen - перейти Йордан, тобто вмерти; nach Bethlehem gehen - йти у Віфлеєм, тобто лягати спати, die babylonische Verwirrung - вавилонське стовпотворіння; die Posaunen von Jericho - ієрихонські труби). Проте більшість топонімів у складі фразеологізмів німецької мови не біблійного походження. Це назви німецьких i європейських міст (Eulen nach Athen tragen, ab nach Kassel, jmd. War in Rom und hat den Papst nicht gesehen, Rom wurde nicht an einem Tag gebaut), річок (Wasser in die Elbe tragen, läuft noch viel Wasser den Rhein hinunter), країн (noch ist Polen nicht verloren).

Асоціації, пов'язані 3 біблійними антропонімами й топонімами, їх сприйняття можуть збігатися повністю, частково або виявляти відмінності. Прикладом ФО, які демонструють повний збіг, є weise wie Salomon / мудрий як Соломон. Ім'я Соломона, що попросив один раз у Бога розумне серце, щоб судити народ і розрізняти добро й зло, асоціюється в німецькій мові (як і вукраїнській) винятково з мудрістю. Пор. також: Хома, асоціюється зі зневірою, тож в обох мовах наявні відповідні ФО (нім. der ungläubige Thomas та укр. Хома невіруючий), які мають однаковий компонентний склад і структуру; Йов у німецькій мові (як і в українській) асоціюється зі стражданнями й бідністю (нім. arm wie Hiob sein та укр. бідний Йов), подекуди набуває додаткових (позитивних чи то негативних) конотацій, як-от: Hiobsgeduld haben - мати терпіння Йова, тобто бути терплячим; eine Hiobspost bringen - приносити звістку Йова, тобто приносити погані новини. Функціонування відміннимх за значенням і структурою фразеологізмів пов'язують із тим, що в основу ФО різних мов покладено різні уривки Біблії. У німецькій мові ім'я Марії Магдалини символізує нерозуміння (das ist mir maria-magdalenisch - я не розумію цього), в українській - цей антропонім асоціюється насамперед із каяттям (каяття Магдалени).

Міжнаціональний характер біблійних виразів засвідчує й ситуації, коли певне власне ім'я, широко представлене у фразеологічному складі німецької мови, відсутнє у фразеології інших мов, як-от, наприклад, антропонім Яков (апостол, що 
звернувся до християн із посланням про віру, і персонаж Старого Заповіту, що працював безкоштовно довгих 7 років у свого тестя пастухом). Пор.: das ist nicht der wahre Jakob - це несправжній Яков, тобто не та людина; wissen, wieviel Sprossen Jakobs Himmelsleiter hat - знати, скільки сходів у сходах Якова, тобто бути занадто розумним; der billige Jakob - дешевий Яков, тобто дешевий працівник; den billigen Jakob ablegen відмовитися від дешевого Якова. Постать Якова виступає як показник надійності, проте у ФО з використанням його імені невідповідність затребуваним показникам передається через додавання прикметника billig (der billige Jakob) або через заперечення (das ist nicht der wahre Jakob).

В українській лінгвокультурі біблійні вислови переосмислюються 3 позиції структурно-семантичних особливостей інгерентних (співвідносних за змістом із первинним текстом Старого й Нового Заповітів, конкретною біблійною ситуацією) й адгерентних (семантика яких зазнала змін упродовж історичного розвитку) відповідників. Алегоричні висловлення розкриваються на прикладі життєвих ситуацій; номінація людини відповідає оцінці, передставленій у першоджерелі (Каӥн, Юда, Мойсей). Такі біблеїзми часто слугують назвами художніх творів, виконують роль морального імператива для народу.

Серед ФО наявна значна кількість таких, які ілюструють імена літературних персонажів (як відомих німецьких письменників, так і народних казок, шванків, легенд та міфів), що стали компонентами фразеологізмів. Так, наприклад, на позначення відданої людини використовують фразеологізм ein treuer Eckart, персонаж німецьких легенд, який став героєм творів Й. В. Гете та Л. Тіка. Окрім того, часто натрапляємо на ім'я Гретхен з “Фауста” Й. В. Гете: Das passt wie [der] Faust aufs Gretchen - підходити. Слід зазначити, що цей фразеологізм $\epsilon$ переосмисленим виразом passen wie die Faust aufs Auge - бути абсолютно непідходящим (кроком, дією тощо); die Gretchensfrage stellen - ставити складне питання.

Здебільшого антропоніми у структурі ФО ідентифікують особу як людину, вказують на іiі стать або уналежнюють іï до 
певної ентічної спільноти [Lukanska, Oleksiienko / Луканська, Олексієнко 2011 : 75], подекуди мають додаткове позитивне або негативне забарвлення. Так, наприклад, серед 20 ФО, репрезентованих у словнику „Deutsche Idiomatik” [Schemann 2011], 16 одиниць передбачають антпопонімічний компонент, що $є$ чоловічими іменами, і тільки 4 - жіночими (ідеться насамперед про поширені в німецькій культурі імена без урахування номінацій персонажів літературних творів), де лише три фразеологізми 3 іменами жінок мають негативне забарвлення (die schnelle Kathrin haben, Lieschen Müller, zu Tante Meier müssen), один (die grüne Minna) - нейтральне і означає “поліцейська машина". Пор.: ФО із чоловічими іменами: Benjamin (der Benjamin der Familie sein - улюбленець сім'ї, наймолодший син); Emil (ich will Emil heißen - назвіть мене дурнем, якщо не ...); Fridolin (wenn ... will ich Fridolin heißen назвіть мене дурнем, якщо не ...); Hans (ein Hans im Glück Ганс, якому щастить; ich will Hans heißen - назвіть мене дурнем, якщо не ... ; die grossen Hansen - поважні особи); Heinrich (den flotten Heinrich haben - мати проблеми з травленням; den müden Heinrich spielen - вішати ніс; sanfter Heinrich - скромна людина); Oskar (frech wie Oskar sein, stolz wie Oskar auftreten бути нахабним, гордим, як Оскар); Otto (den flotten Otto haben мати проблеми 3 травленням; Otto Normalverbraucher пересічний споживач). Більшість антропонімів у складі фразеологізмів мають давню історію, завдячують своєю появою кмітливості мешканців територій, які є сьогодні частиною ФРН. Наприклад: Hinz und Kunze - кожен, будь-хто; з'явився в епоху Середньовіччя, коли поширеними були відповідні імена (Heinrich та $\mathrm{Konrad),} \mathrm{які} \mathrm{набули} \mathrm{популярності} \mathrm{у} \mathrm{скороченій} \mathrm{формі.}$

Зрідка використовуваними є ФО, компонентами яких виступають імена особистостей, що відіграли в історії Німеччини певну роль (dazu hat Buchholtz kein Geld - на це Бухгольца не має грошей, тобто на це немає грошей (фразееологізм увічнив ім'я скарбника Бухгольца). Пор.: nach Adam Riese - по Адаму Ризі, тобто за всіма правилами арифметики (ім'я А. Ризі, відомого в XVI в. у Німеччині укладача підручників із арифметики, мало знайоме 
представникам інших культурних спільнот); das ist für den Alten Fritzen - це для Старого Фрица, тобто даремно, безрезультатно й непотрібно; sich beim Alten Fritzen im Hauptquartier meldenпомерти; den Alten Fritzen besuchen - відвідати Старого Фрица, тобто вмерти (актуалізують ім'я пруського короля Фрідріха Вільгельма I); Kotzebues Werke studieren, so was lebt und Schiller mußte sterben - таке живе, а Шилер мав померти, rangehen wie Blücher - упевнено йти вперед, seinen Friedrich Wilhelm unter etwas setzen - поставити підпис під документом. Для розуміння значення таких ФО необхідні грунтовні фонові знання щодо названих осіб, їх способу життя, ролі в історії і т. ін.

Структурною особливістю українських фразеологізмів $\epsilon$ ритмотворча роль імені, причому перевага у використанні того чи того номена увиразнює вислів як експресивну одиницю. Українські фразеологізми 3 антропонімним компонентом актуалізують культурно-історичну інформацію; дають змогу дослідити специфіку національного світогляду; характеризують за оцінною шкалою поведінку людини; розкривають не лише народні традиції, але й відтворюють етичний кодекс, реалізуючи потужний виховний потенціал.

Музикальність фразеологізмів досягається через римування, причому експресивності надають розмовні варіанти антропонімів, які утворюються шляхом додавання демінутивних / майоративних суфіксів. Звертаємо увагу на те, що для системи українського іменника́ характерним $є$ розгалужена система суфіксальних утворень: Григорій - Григор (Григорко, Григорочка; Гринь - Гриник, Гринько; Грищь, Грицько, Гриценко, Грицик, Грищеня, Грищина; Грищь - Грищюня (Грииунь), Грииуня, Грииуник, Грииунчик; Грищь - Грищюнь, Грищюньо; Грищь Гриценятко, Гриченяточко).

Українська лінгвокультура репрезентує відповідність хресних імен у канонічній формі й розмовних варіантів. Наприклад: Агата (Агафія) - Гафія, Гафійка, Гапка, Гапа: Балакайте, Гапко, бо я люблю слухать - негативна або глузлива характеристика мовлення когось, що характеризується беззмістовністю, нелогічністю, незначущістю, викривленням фактів; Не твоє діло, Самійло, про ие Гапка знає [Rosiisko- 
ukrainskyi / Російсько-український 2016 : 30] - відсутність потреби в допомозі кого-небудь 3 причини іï непотрібності, малозначущості; такої, що применшує саму значущість допомоги; Голодній Гапці (кумі) хліб на гадияі (на умі) [Rosiisko-ukrainskyi / Російсько-український 2016 : 73] - хтось розмірковує чи думає про те, чого потребує; що для нього є життєво необхідним / синонімізує з поширеним відповідником Кому щзо, а куриі просо; Заробила Гапка бісового батька [Ukrainski / Українські 1993 : 610] - лінива жінка; Що Гапці на вухо, то ци Векла знатиме [Ukrainski / Українські 1993 : 549] - язиката жінка; То ще дурна Гаna [Ukrainski / Українські 1993 : 79] - недалекоглядна жінка; Федір - Тодось, Федось, Хведось, Хвесь: Увесь Хвесь - голова та ноги [Rosiisko-ukrainskyi / Російсько-український 2016 : 72] відсутність матеріального статку або його низький рівень; матеріальні труднощі; y перен. зн. - складна життєва ситуація, неможливість знайти конструктивний вихід зі складних обставин.

Використання розмовних назв репрезентує синкретизм значень категорій зменшеності/збільшеності, оскільки вони перебувають у тісному взаємозв'язку з об'єктивним оцінюванням; позитивним і негативним суб'єктивним оцінюванням мовцем кого-, чого-небудь. Іншими словами, фразеологізми з розмовними варіантами реалізують конотацію зменшеності-оцінності, зменшеності-емоційності, зменшеностіекспресивності, збільшеності-оцінності, збільшеностіекспресивності. Оскільки оцінка й емоційність корелюють на рівні конотацій, говоримо про досягнення гумористичного, виховного, викривального тощо ефекту при використанні фразеологізмів із власним ім'ям 3 оцінним значенням, яке реалізують словотворчі засоби.

В українській лінгвокультурі кількісно переважають фразеологізми 3 жіночими розмовними варіантами, репрезентуючи відповідний спектр конотативних відтінків. За нашим спостереженням, найбільш уживаними $є$ такі антропоніми:

- жіночі (Анастасія, Настя, Настка; Анна, Ганна; Галина, Галя; Дарина, Одарка; Свфимія, Хима, Химка; Катерина, Катря; Кристина, Христина, Христя; Марія, Маруся; Мотрона 
(Мотрина), Мотря; Пелагея, Палажка, Палагна; Парасковія, Пріська; Стефанія, Степанида, Стеха; Соломія, Солоха; Фефронія, Хавронія, Хівря);

- чоловічі (Василь, Васько; Гаврило; Григорій, Гриць, Грицько; Дем'ян, Демко; Дмитро, Митя, Митько; Евстафій, Ocman, Стах; Іван, Іванко, Івась; Йосип, Осип; Кузьма; Макар; Мартин, Марко; Опанас, Панас, Панько; Павло; Парфемій, Пархім; Пилип, Філько; Сава, Савка; Савелій, Савка; Самійло, Семен; Спиридон, Свирид; Федір, Теодор, Тодось, Федось, Хведось, Хвесь; Фома, Хома, Хомко; Юрій, Георгій [Chuchka / Чучка 2011].

Залежно від способу отримання цих оцінних кваліфікацій розрізняють абсолютну (передбачає оцінні стереотипи носіїв мови) й порівняльну (спирається на порівняння, суть якого полягає в тому, що оцінювана ознака, властивість порівнюється зі стандартом, зразком, що слугує за норму) оцінки, що дає змогу говорити про “оцінну шкалу” як імпліцитний елемент структури оцінки. Шкала виконує роль засобу створення емотивно-оцінних значень слів і виразів, містить не тільки вказівку на ступінь наростання / спадання якоїсь якості, а й відображає певну оцінну модифікацію цієї якості як стереотип чи стереотипи, характерні для мовної картини світу певної лінгвокультурної спільноти, що істотно відрізняє ії від власне оцінної шкали [Bessonova / Бессонова 1995 : 8-16].

Індивідуалізовані власні імена, використані задля позначення певного явища або характеристики окремих рис людини / загальної характеристики вдачі; оцінки поведінки людини відповідно до етичного кодексу; відтворення світоглядної позиції нації (когнітивний, емоційний рівні пізнання світу), поступово виконують роль засобу типізації. Наприклад, фразеологізм Христя в намисті використовується задля підкреслення неохайного, недоладного, нечепурного, без смаку вигляду; недоречного поєднання буденного одягу зі святковим тощо. У типізованому значенні йдеться про людину, яка має нечепурний, неохайний вигляд.

Власні назви-образи використовуються як іменахарактеристики, причому синонімічні ФО засвідчують 
вибірковість. Прикладом слугує характеристика жінки, яка надмірно говорить, іiі мовлення вирізняється беззмістовністю, неактуальністю й незв'язністю. У наведеному ряді аналізована характеристика переважно асоціюється 3 іменами Палажка і Параска, Хвеська, поодиноко - Гапка: Баба Палажка $і$ баба Параска [Frazeolohichnyi / Фразеологічний 1993 : 16]; Язиката Хвеська [Ukrainski / Українські 1993 : 57]; Що Гапці на вухо, то й Векла знатиме [Ukrainski / Українські 1993 : 549] - язиката, пихата, чванлива. У такий спосіб, у структурі фразеологізмів особові імена класифікуються як “соціалізовані”, тобто зрозумілі носіям української лінгвокультури.

Зауважимо, що в українській мові переважають негативно оцінні фразеологізми $з$ особовими назвами, меншою мірою нейтральні й позитивно оцінні. Будучи використаними як структурно-семантичний компонент, імена надають оцінної експресії, фактично “номінують” людину цим ім'ям, що не тільки увиразнює оцінку, але й градаційно підкреслює актуалізовану рису вдачі / особливість поведінки: жіночі імена (Палажка, Параска, Хвеська, Гапка - язиката; Химка - недалекоглядна, обмежена; лінива; Христя - неохайна; Солоха - неуважна, нерозумна); чоловічі імена (Гриць - простакуватий; роботящий; Хома, Пилип - невдаха, недалека людина, некультурний; Стецько, Кіндрат, Кирило - недоумкуватий). Пор.: Дурного Кирила і Химка побила [Ukrainski / Українські 1993 : 99] знущання над кимось наївним, беззахисним (фізично чи морально), недосвідченим тощо, де експресивний ефект досягається протиставленням антропонімів, що реалізують усталені конотації Химка - недоумкувата, упосліджена, яка має незначний статус у громаді, не викликає поваги. Українська фразеологія репрезентує одиниці, у яких основне значення реалізує ад'єктив, указуючи на рису вдачі людини чи ситуацію: кисла Оришка [Ukrainski / Українські 1993 : 588] - тонкосльоза; лепетливий Савочка [Ukrainski / Українські 1993 : 201] балакучий; пізній Іван [Ukrainski / Українські 1993 : 92] на позначення поняття “запізно” за усталеними рамками.

Фонетичне звучання ономастичного компонента додатково конотує основне значення, поступово здатне 
заступати власне антропонім. Наведені вище етимологічні відповідники власних імен, використовуваних в українських фразеологізмах, як бачимо, не актуалізуються в загальному значенні. Вільні семантичні асоціації зумовлюють розвиток конотацій, грунтованих на псевдокоренях: Варка варила вареники, Василь варив вареники, Василь Варку вареником! [Frazeolohichnyi / Фразеологічний 1993], де спостерігаємо явище парономазії, побудованої на основі стягнення значення кореня вар- (варити, вареник) зі структурною частиною імені Bарвара. Пор.: Тягніть-но Варвару на розправу [Rosiisko-ukrainskyi / Російсько-український 2016 : 113-114] - вимога дії попри волю іншого або справедливе покарання.

Фразеологізми 3 ономастичним компонентом здатні виконувати функцію займенникових замінників, причому семантичне ядро почасти перебирає на себе не ономастичний складник, а яскрава характеристика, виражена загальною назвою. Чоловік / (дівчина) жінка: Любили Якова, та не всякого [Frazeolohichnyi / Фразеологічний 1993]; Не кожна ж Ганна гарна [Frazeolohichnyi / Фразеологічний 1993]; Наша Галя як краля, та тільки душа невмивана [Rosiisko-ukrainskyi / Російськоукраїнський 2016 : 154] - невідповідність зовнішньої краси (гармонійне поєднання ліній зовнішності як еталон краси) i внутрішнього деструктивного стану, що характеризується негативними якостями, які засвідчують невихованість, підступність, підлість людини, деструктивність у розв'язуванні конфліктів; Бісів Юхим - $i$ з води вийде сухим [Rosiisko-ukrainskyi / Російсько-український 2016 : 165] - характеристика людини, яка 3 допомогою хитрощів, кмітливості виходити зі складних ситуацій; Катерина та Василь посварилися за кисіль / Катерина та Дем'ян посварились за бур'ян [Rosiisko-ukrainskyi / Російськоукраїнський 2016 : 85] - хтось сперечається через незначну причину; деструктивний конфлікт, який супроводжується взаємними образами і приниженнями; Парочка - Мартин да Одарочка [Rosiisko-ukrainskyi / Російсько-український 2016 : 273] - характеристика подружжя, які подібні за якостями, поведінкою; суспільна негативна характеристика аморальної поведінки подружжя; Прилип, як до Гандзі Пилип [Rosiisko-ukrainskyi /

() В. Гаманюк, Т. Мішеніна, 2019. 
Російсько-український 2016 : 107] - характеристика ситуації спілкування: 1) набридання низкою питань, висунення почасти неправомірних вимог; 2) намагання звернути на себе увагу, наполегливе переслідування задля більш близького спілкування; Зліпила Оришка: ні караван ні шишка [Ukrainski / Українські 1993 : 612] - про невмілу, неохайну жінку.

Функціональними також є фразеологічні одиниці, у яких антропонім не вказує на вище зазначені кореляції, і загальне значення може стосуватися як чоловіка, так і жінки, оскільки відтворюють ситуацію, вказують на закономірність, оцінюють типову поведінку: непотрібність чогось, що пропонується (На тобі, Даниле / Гавриле, щзо мені немиле [Ukrainski / Українські 1993 : 560]; Не вмер Данило - болячка вдавила [Ukrainski / Українські 1993 : 361]; Не вмер Гаврило - галушка вдавила [Ukrainski / Українські 1993 : 361]); характеристика жадібної людини (Розпережися, Максиме, може ще поміститься [Ukrainski / Українські 1993 : 562]; беззмістовна інформація (Дощик за горами, а Маруся змокла / Здрастуй, Mapiє, я твій Федір [Rosiisko-ukrainskyi / Російськоукраїнський 2016 : 67]); ситуація несхвалення (3 Богом, Парасю [Frazeolohichnyi / Фразеологічний 1993 : 42] - уживається для вираження незадоволення, несхвалення).

Характеристика ситуації / стану може позначатися фразеологізмом, де антропонім реалізує експресію. В українській лінгвокультурі на позначення фізичного стану проблеми з травленням - використовується фразеологізм 3 жіночим ім'ям: швидка Настя; Бігає, як Настя в конопельки [Ukrainski / Українські 1993 : 310].

ФО $з$ антропонімним складником здатні містити фонові знання, які стосуються культурно-історичного тла, що сприяв розвику ономастичного архетипу, який стає інтеріоризованим у світоглядній картині світу, сприймається як “типовий представник нації”, наприклад, Іван у складі фразеологізмів, реалізуючи низку значень:

- соціальний статус, відповідність статусу: Що вільно панові, то не вільно Іванові [Ukrainski / Українські 1993 : 86]; Пан з паном, а Іван з Іваном [Ukrainski / Українські 1993 : 87]; Не 
буде з Івана пана [Ukrainski / Українські 1993 : 97]; Іван не пан, а сто золотих не гроші [Ukrainski / Українські 1993 : 263]; відповідність сімейному статусу (Іван плахту носить, а Настя булаву [Rosiisko-ukrainskyi / Російсько-український 2016 : 69] невідповідність усталених обов'язків, підвладність комусь, хто має виконувати інші функції; імпліцитна апеляція до необхідності змінити життєву позицію, відповідати певному статусу);

- негативна оцінка підступної поведінки: Я свою вину на Івана зверну [Ukrainski / Українські 1993 : 602];

- характеристика рис людини: інтелектуальні характеристики, здоровий глузд (Бас гуде, скрипка грає, Іван мовчить, та все знає; Я говорю про Івана, а ти - про болвана [Ukrainski / Українські 1993 : 364] - розумний, досвідчений; Мудрий Іван по шкоді: коні вкрали, тоді він стайню зачинив [Ukrainski / Українські 1993 : 78] - недотепа, нерозумний); характеристика долі - життєвих ситуацій (Нашому Івану нема талану [Ukrainski / Українські 1993 : 79] - безталанний); характеристика працелюбності (Кобилка біжить, Ванько лежить [Ukrainski / Українські 1993 : 89] - ледачий); моральний імператив (Кажу Іванові: бери на сухо, а він зайхав на бухо [Ukrainski / Українські 1993 : 265] - неслухняний, впертий; Не смійся, Іванку, з чужсого припадку [Rosiisko-ukrainskyi / Російсько-український 2016 : 189] - моральний імператив, який апелює до емпатії до того, хто опинився у складній життєвій ситуації; етична неприпустимість отримувати задоволення від споглядання біди іншого; загальна характеристика уподобань людини (Івась має свій лас [Rosiisko-ukrainskyi / Російсько-український 2016 : 159] констатація того, що сформовані смаки можуть бути різними, тому не можуть становити предмет безглуздих сперечань).

Соціальна характеристика певних антропонімів поступово набуває узуального статусу, що сприяло розвиткові соціальнооцінних конотацій. Прикладом в українській лінгвокультурі може слугувати антропонім Хома, позначений переважно негативно оцінними характеристиками: відповідність статусу чоловіка, господаря (У мене Хома - й добра нема [Rosiisko-ukrainskyi / Російсько-український 2016 : 19] - негативна характеристика рис чоловіка; загальна негативна характеристика сімейного життя, 
яке не відповідає загальному кодексу співжиття (неможливість конструктивного діалогу, відсутність гармонії в родині, різні погляди стосовно виховання дітей; неможливість дійти згоди щодо спільного господарства); ситуація досягнення добробуту (Заробив, як Хома на вовні (на качалках) / Заробила Гапка чортового батька [Rosiisko-ukrainskyi / Російсько-український 2016 : 112] - підкреслення невідповідності докладених зусиль, спрямованих на досягнення мети чи матеріальних засобів, оплати за виконану працю / вдячності за зроблене); сприймання громадою людини, яка має статки (Якби Хомі громі, був й він хороший, <а як нема, то й усяк мина> [Rosiisko-ukrainskyi / Російсько-український 2016 : 113] - констатація закономірності, яка полягає в тому, що тому, хто має матеріальні статки, як правило, виказують пошану, доброзичливе ставлення тощо); типовість удачі, прогнозованість поведінки людини (I ззаду знати, щуо Хомою звати / Видно й з рила, щчо Пархім / Глянь на вид та й скажи, щчо Свирид [Rosiisko-ukrainskyi / Російськоукраїнський 2016:117] - неможливість приховати риси характеру, дії, стан, наміри, манери від кого-небудь, замаскувати що-небудь чим-небудь; видавати себе не того, яким є насправді); вибірковість (На безлюдді і Хома чоловік [Rosiisko-ukrainskyi / Російсько-український 2016 : 158] - незважаючи на об’єктивну невідповідність зразковій поведінці, статусу, через відсутність достойного супротивника мають справу з тим, хто його заступає; послуговання тим, що наявне); розумові здібності; здоровий глузд (Хома не без ума: не б'є жінку, а тешу [Rosiisko-ukrainskyi / Російсько-український $2016: 186]$ - нелогічність дій, спрямованих на покарання когось); Не тільки людей, щзо Хома $в$ церкві [Rosiisko-ukrainskyi / Російсько-український 2016 : 191] спонукання до активних дій і вибору альтернатив у досягненні мети); життєва мудрість щодо лінії поведінки в певній ситуації; рекомендації (Не будь Хомою (не зівай, Химко): на те ярмарок [Rosiisko-ukrainskyi / Російсько-український 2016 : 221] - життєва настанова бути уважним, щоб не стати жертвою обману когось); поведінка, яка характеризується незначними досягненнями; невідповідністю результатам (Om і крути, Хомо, головою / Труби, Грицю, в рукавицюю [Rosiisko-ukrainskyi / Російсько-український

-47- С В. Гаманюк, Т. Мішеніна, 2019. 
2016 : 222] - характеристика несерйозної людини, яка нераціонально витрачає свої сили й час на щось незначне, що не заслуговує на увагу, що може призвести до негативних наслідків); характеристика непевної людини (Іхав до Хоми, а заїхав до куми [Rosiisko-ukrainskyi / Російсько-український 2016 : 104] підкреслення несталості планів когось, їх швидкої зміни; негативна характеристика людини, яка швидко змінює рішення, $\epsilon$ ненадійною у складних ситуаціях).

Позитивна характеристика людини, де антропонім становить омонімічний корелят римуванню (Кому Хома, а кому нема [Rosiisko-ukrainskyi / Російсько-український 2016 : 126] філософське узагальнення причино-наслідкових закономірностей, які визначають долю людини, низку ситуацій, наявних у іï житті; непізнанну логіку Божого промислу, що визначає щасливу / нещасливу долю людини).

Активним функціонуванням позначені ФО 3 поширеною власною назвою в українській культурі: Не для Гриця паляниця [Rosiisko-ukrainskyi / Російсько-український 2016 : 103] підкреслення закономірності того, що незароблені, недосягнуті матеріальні статки чи будь-які цінності, створені не власними зусиллями, не можуть бути чиєсь властністю; імператив заборони на розраховування на незароблене, чуже; Без Гриця й вода не освятиться; Велике свято, щчо Гриць у иеркві [Frazeolohichnyi / Фразеологічний 1993] - непотрібність, неважливість чиєїсь допомоги / присутності; Не микайся, Грицю, на дурнищю <бо дурниця тобі боком вилізе> [Rosiiskoukrainskyi / Російсько-український 2016 : 169] - моральний імператив, який стосується категоричної неможливості прагнути заволодіти чужим добробутом; мати те, що має хтось інший.

Використовуваними $є$ фразеологізми 3 антропонімами, які уживається і як омонімічні атрактанти, і як власна назва, найбільш уживана в період поширення канонічних імен: Ось тобі, Савко, булавка [Rosiisko-ukrainskyi / Російськоукраїнський 2016 : 197] - довіра неправдивій інформації, обіцянкам когось зробити певні дії в його інтересах; безпідставна радість; Який Сава, така й слава / Який Яким, стільки й дяки [Rosiisko-ukrainskyi / Російсько-український 2016 : 211] - 
моральний імператив, який визначає закономірність статусу у громаді, визнання, вияв поваги й шанобливого ставлення до людини 3 огляду на відповідну достойну поведінку й гідні вчинки; По Савці <панові, синові> і свитка (шапка) [Rosiiskoukrainskyi / Російсько-український 2016 : 212] - закономірність, яка полягає у справедливій відповідності здатностей, можливостей, досягнень, наполегливої праці і статусу, посади; відповідність умов, у яких перебуває людина залежно від іiі наполегливості; Спочине Савка на голій лавцчі [Rosiisko-ukrainskyi / Російсько-український 2016 : 267] - характеристика людини, яка важко й постійно працює, тому не має часу на дозвілля чи відпочинок, незначну перерву в роботі; Бідному Савці нема долі ні на печі, ні на лавці / На бідного Макара всі шишки летять / На бідного Хому $i$ дерево падає [Rosiisko-ukrainskyi / Російськоукраїнський 2016 : 158] - закономірність насиченості негативних подій у житті того, хто має в розумінні низки складних ситуацій $\mathrm{i}$ подій нещасну долю; Той же Савка, та на других санках [Rosiisko-ukrainskyi / Російсько-український 2016 : 84]; Зібралися два Юрії, та й обидва дурнії - подібність рис (переважно негативних) когось, хто перебуває в родинних або дружніх стосунках; вірогідність деструктивної поведінки.

Українська лінгвокультура репрезентує синонімічні ФО, до структури яких входять різні чоловічі й жіночі антропоніми:

- характеристика мовлення (Блей, пане Свириде, побачим, щчо з того вийде / Говорив Мирон рябої кобили сон / Говори, Климе, нехай твоє не гине / Балакайте, Гапко, бо я люблю слухать / Химині кури / Мотрині яйя / Мели, Денисе, погода тягне / Мели, Іване, доки вітру стане / Правда Сидорова киселем млиниі помазані, на паркані сушаться [Rosiiskoukrainskyi / Російсько-український 2016 : 102] - негативна або глузлива характеристика мовлення когось, що характеризується беззмістовністю, нелогічністю, незначущістю, викривленням фактів тощо);

- характеристика хронотопу (За изаря Гороха, коли людей було трохи / За царя Горошка, коли луб'яне небо було, а шкуратяні гроші ходили / За царя Митрохи, коли людей було трохи / За иаря Панька (Тимка), коли земля була тонка:

-49- () В. Гаманюк, Т. Мішеніна, 2019. 
пальцем проткни ци води напийся [Rosiisko-ukrainskyi / Російсько-український 2016 : 85-86] - підкреслення часової віддаленості ситуації, події; відповідного натяку на незначущість або непотребу на іiі актуалізації; пор.: Де Макар телят не пас / Куди Макар телят не ганяв / Там, де Макар телят пасе - дуже далеко, там, туди, де важкі умови, де перебувають не з власного бажання [Frazeolohichnyi / Фразеологічний 1993 : 95]);

- характеристика поведінки (Вискочити (вистрибнути) як Пилип (голий Кузьма) з конопель / вискакувати, як Марко $з$ пасльону [Frazeolohichnyi / Фразеологічний 1993 : 85] недоречно, недоладно або невчасно зробити, сказати що-небудь чи виступити з чимсь);

- характеристика стилю, порядку життя (У кожного Мусія своя затія / У всякого Павла своя правда / Кожна Ганна посвоєму гарна [Rosiisko-ukrainskyi / Російсько-український 2016 : 61] - відтворення ситуації як векторна проекція поведінки, яка розглядається на рівні когнітивного узагальнення, типовості; ідеться про можливість варіативності світоглядних поглядів, довільності вибору поведінки в рамках кодексу; У кожної Меланки свої забаганки [Rosiisko-ukrainskyi / Російськоукраїнський 2016 : 49] - вирізняють поведінку (на рівні оцінної шкали), світоглядні позиції, характерні реакції в типових ситуаціях (зумовлені як особливостями культури, так і рівнем виховання людини);

- характеристика поведінки, якості зробленої праці: Пішов Oпанас по горілку для нас, <зачепився за пень та й простояв цілий день> / Пішов Тарас за лозами [Rosiisko-ukrainskyi / Російсько-український 2016 : 219] - незадовільне, недбале, повільне виконання обов'язків; повільне виконання будь-якої справи;

- характеристика спілкування: Говори до гори, Григоре / Толкуй, Захаре, з бабою [Rosiisko-ukrainskyi / Російськоукраїнський 2016 : 260] - неможливість налагодження конструктивного діалогу через асиметрію комунікативних намірів, неможливість порозуміння.

До системи українського іменника́ уналежнюють родичівські прізвиська, неофіційні найменування дружин, синів 
і дочок 3 допомогою суфіксів -ux(a), -к(a), -енк(o), -івн(a): Коваль - Ковалиха, Коваленко, Ковалівна; Митюк - Митючка, Митюченко, Митюківна. Відповідно, функціональними є ФО, зрозумілі для представників української кульутри: За Панасом Панасиха / <3a Іваном Іваниха> [Rosiisko-ukrainskyi / Російсько-український 2016 : 111] - підкреслення ваги статусу родини, у якій чоловік має повагу, розв'язує складні питання; ставлення до дружини безпосередньо залежить від ставлення до iii чоловіка, чоловіка до дружини; етичний кодекс побудови доброчесної родини, повага до того, хто має такий статус.

Українська лінгвокультура репрезентує ФО з жіночими власними назвами, що відтворюють настанову, якою має бути жінка (дружина / господиня / матір): Зліпила Оришка: ні караван ні шишка [Ukrainski / Українські 1993 : 612] - про невмілу, неохайну жінку; Не велика Стеха пані, тим щзо сіла в панські сани [Ukrainski / Українські 1993 : 617] - яка вдає з себе велику пані; Це тая Солоха, щзо кури полоха [Rosiisko-ukrainskyi / Російсько-український 2016 : 154] - характеристика людини, яка демонструє удавану рішучість, сміливість в умовах, які не відповідають поняттю складних, небезпечних або в яких він почувається впевнено; в умовах, де протистоять нерівноправні сили; Заторохтіла Солоха, як бочка з горохом / Леська та Хвеська хоч якого дзвона перегудуть [Rosiisko-ukrainskyi / Російсько-український 2016 : 224] - хтось говорить нісенітницю, висловлює безглузді речі; характеристика мовлення надшвидкого, безперервного, що підкреслює неважливість i беззмістовність інформації; Нашій Катрі полешало: то не їла, а mепер $і$ не балакає [Rosiisko-ukrainskyi / Російсько-український словник паремій 2016 : 221] - незворотнє погіршення стану здоров'я, втрата надії на одужання, відчуття близької смерті.

Висновки й окреслення перспективи подальших розвідок. Основні компоненти структури лексичного значення ФО $з$ ономастичним компонетом (когнітивний, або предметнологічний; граматичний; конотативний) моделюють особливості їх значеннєвих реалізацій або стилістичних ознак. Семантична структура ФО передбачає також лексико-семантичний відтінок, який співвідноситься 3 асоціаціями, закріпленими за 
ономастичним компонентом, визначає специфіку лексикосемантичної системи мовної системи. Конотативний аспект зіставлення розкриває особливості формування та вживання оцінних значень антропонімного складника в зіставлюваних мовах: установлено відповідники, які мають як спільні, так і відмінні лексико-семантичні варіанти оцінного характеру 3 позиції антропоцентричного моделювання мовної дійсності.

Під час перекладу ФО $з$ ономастичним компонентом необхідно враховувати лінгвістичні чинники (нетотожна, почасти неспіввідносна, категоризація дійсності носіями мови; наявність етнографічних лакун - лексичних одиниць, які означають реалії носіїв вихідної мови і не мають відповідників у мові перекладу), що дає змогу дібрати ФО залежно від вибору відповідника в мові перекладу: переносного чи образного; прямого / предметного / образного / емоційного; національно-етнічного компонента. Перспективи подальших розвідок убачаємо у виявленні загальної семантики, національно позначеної семантики власних назв, здійсненні лексикографічної й пареміографічної репрезентації ФО 3 ономастичним компонентом на основі контрастивних зіставлень.

\section{Література}

1. Бессонова О. Л. Оценка как семантический компонент лексического значения слова : автореф. дис. ... канд. филол. наук. Донецк, 1995. 20 с.

2. Гаврись В. І., Пророченко О. П. Німецько-український фразеологічний словник. Deutsch-Ukrainisches phraseologisches Worterbuch. Т. 1-2. Київ : Рад. шк., 1981.416 с.; 382 c.

3. Кочерган М. П. Загальне мовознавство : підручник. 2 вид., випр. і доп. Київ : ВЦ “Академія”, 2006. 463 с.

4. Лалаян Н. Генетичні типи та джерела походження ономастичної фразеології (на матеріалі німецької мови). Наукові записки Кіровоградського державного педагогічного університету імені Володимира Винниченка. Серія : Філологічні науки. 2009. Вип. 81 (1). С. 137-141. URL: http://nbuv.gov.ua/ UJRN/Nzs_2009_81(1)_35.

5. Лалаян Н. С. Фразеологічні одиниці 3 ономастичним компонентом у сучасній німецькій мові: структурно-семантичний та функціональний аспекти : дис. ... канд. філол. наук. Одеса, 2008. 180 с.

6. Луканська Г. А., Олексієнко Л. І. Національно-культурна специфіка англійських фразеологічних одиниць з власними назвами: основні підходи до виявлення. Мова і культура. 2011. Вип. 14. Т. 8. С. 74-81. URL : http://nbuv. gov.ua/UJRN/Mik_2011_14_8_12 
7. Манакін В. М. Мова і міжкультурна комунікація. Київ : ВЦ “Академія”, 2012. $288 \mathrm{c}$.

8. Мороз О. А. Ономастична фразеологія в українській та польській мовах в національно-культурному слов'янському просторі. Наукові праиі. Філологія. Мовознавство. 2016. Вип. 66. Т. 278. С. 77-81.

9. Позніхіренко Ю. І. Мотиваційна база ергонімів як знаків соціокультурного простору України й англомовних країн (на матеріалі назв закладів харчування) : дис. ... канд. філол. наук. Київ, 2018. 264 с.

10. Російсько-український словник паремій / Ж. В. Колоїз, 3. П. Бакум, Л. А. Білоконенко, Т. І. Вавринюк, Н. М. Малюга, Н. М. Шарманова ; за ред. проф. Ж. В. Колоїз. Кривий Ріг : ФОП Маринченко С. В., 2016. 454 с.

11. Українські приказки, прислів'я і таке інше / упоряд. М. Номис. Київ : Либідь, 1993. 768 с.

12. Фразеологічний словник української мови : у 2-х кн. / уклад. : В. М. Білоноженко та ін. Київ : Наукова думка, 1993. 984 с.

13. Чучка П. П. Слов'янські особові імена українців: історикоетимологічний словник. Ужгород : Ліра, 2011. 432 с.

14. Ящик Н. П. Лексико-семантична характеристика німецьких антропонімів-синонімів. Молодий вчений. Філологічні науки. 2017. № 8 (48). C. $156-169$.

15. Duden. Redewendungen und sprichwörtliche Redensarten. Mannheim, Leipzig, Zürich : Dudenverlag, 1998. $864 \mathrm{~s}$.

16. Klappenbach R. Feste Verbindungen in der deutschen Gegenwartssprache. Halle, 1971.300 s.

17. Küpper H. Wörterbuch der deutschen Umgangssprache. Stuttgart: Klett, 1990. $960 \mathrm{~S}$.

18. Schemann H. Deutsche Idiomatik. Wörterbuch der deutschen Redewendungen im Kontext. Berlin: De Gruyter, 2011. 1050 s.

19. Wörter und Wendungen. Wörterbuch zum deutschen Sprachgebrauch / E. Agricola, H. Gorner, R. Kufner. Leipzig, 1972. 996 s.

\section{References}

1. Bessonova O. L. Otsenka kak semanticheskiy komponent leksicheskogo znacheniya slova : avtoref. dis. ... kand. filol. nauk. Donetsk, 1995. $20 \mathrm{~s}$.

2. Havrys V. I., Prorochenko O. P. Nimetsko-ukrainskyi frazeolohichnyi slovnyk. Deutsch-Ukrainisches phraseologisches Worterbuch. T. 1-2. Kyiv : Rad. shk., 1981. 416 s.; $382 \mathrm{~s}$.

3. Kocherhan M. P. Zahalne movoznavstvo : pidruchnyk. 2 vyd., vypr. i dop. Kyiv : VTs "Akademiia", 2006. $463 \mathrm{~s}$.

4. Lalaian N. Henetychni typy ta dzherela pokhodzhennia onomastychnoi frazeolohii (na materiali nimetskoi movy). Naukovi zapysky Kirovohradskoho derzhavnoho pedahohichnoho universytetu imeni Volodymyra Vynnychenka. Seriia : Filolohichni nauky. 2009. Vyp. 81 (1). S. 137-141. URL : http://nbuv.gov.ua/ UJRN/Nzs_2009_81(1)_35. 
5. Lalaian N. S. Frazeolohichni odynytsi z onomastychnym komponentom u suchasnii nimetskii movi: strukturno-semantychnyi ta funktsionalnyi aspekty : dys. ... kand. filol. nauk. Odesa, 2008. $180 \mathrm{~s}$.

6. Lukanska H. A., Oleksiienko L. I. Natsionalno-kulturna spetsyfika anhliiskykh frazeolohichnykh odynyts z vlasnymy nazvamy: osnovni pidkhody do vyiavlennia. Mova i kultura. 2011. Vyp. 14. T. 8. S. 74-81. URL : http://nbuv. gov.ua/UJRN/Mik_2011_14_8_12

7. Manakin V. M. Mova i mizhkulturna komunikatsiia. Kyiv : VTs “Akademiia", 2012. $288 \mathrm{~s}$.

8. Moroz O. A. Onomastychna frazeolohiia v ukrainskii ta polskii movakh v natsionalno-kulturnomu slovianskomu prostori. Naukovi pratsi. Filolohiia. Movoznavstvo. 2016. Vyp. 66. T. 278. S. 77-81.

9. Poznikhirenko Yu. I. Motyvatsiina baza erhonimiv yak znakiv sotsiokulturnoho prostoru Ukrainy y anhlomovnykh krain (na materiali nazv zakladiv kharchuvannia) : dys. ... kand. filol. nauk. Kyiv, 2018. $264 \mathrm{~s}$.

10. Rosiisko-ukrainskyi slovnyk paremii / Zh. V. Koloiz, Z. P. Bakum, L. A. Bilokonenko, T. I. Vavryniuk, N. M. Maliuha, N. M. Sharmanova ; za red. prof. Zh. V. Koloiz. Kryvyi Rih : FOP Marynchenko S. V., 2016. 454 s.

11. Ukrainski prykazky, pryslivia i take inshe / uporiad. M. Nomys. Kyiv : Lybid, 1993. $768 \mathrm{~s}$.

12. Frazeolohichnyi slovnyk ukrainskoi movy : u 2-kh kn. / uklad. : V. M. Bilonozhenko ta in. Kyiv : Naukova dumka, 1993. $984 \mathrm{~s}$.

13. Chuchka P. P. Slovianski osobovi imena ukraintsiv: istoryko-etymolohichnyi slovnyk. Uzhhorod : Lira, 2011. $432 \mathrm{~s}$.

14. Yashchyk N. P. Leksyko-semantychna kharakterystyka nimetskykh antroponimiv-synonimiv. Molodyi vchenyi. Filolohichni nauky. 2017. № 8 (48). S. $156-169$.

15. Duden. Redewendungen und sprichwörtliche Redensarten. Mannheim, Leipzig, Zürich : Dudenverlag, 1998. $864 \mathrm{~s}$.

16. Klappenbach R. Feste Verbindungen in der deutschen Gegenwartssprache. Halle, 1971.300 s.

17. Küpper H. Wörterbuch der deutschen Umgangssprache. Stuttgart: Klett, 1990. $960 \mathrm{~S}$.

18. Schemann H. Deutsche Idiomatik. Wörterbuch der deutschen Redewendungen im Kontext. Berlin: De Gruyter, 2011. 1050 s.

19. Wörter und Wendungen. Wörterbuch zum deutschen Sprachgebrauch / E. Agricola, H. Gorner, R. Kufner. Leipzig, 1972. 996 s.

Стаття надійшла до редакиії 22.10.2019 p. Прийнята до друку 19.11.2019 p. 